\title{
RESENHA - O REENCONTRO COM KERALA
}

Fábio Guedes Gomes

O estado indiano de Kerala, diferentemente da região da Toscana, na Itália, ou do Vale do Silício, o Silicon Valley, no Estado norte-americano da Califórnia, não está no radar e, menos ainda, na agenda dos estudiosos brasileiros do desenvolvimento local. É mínima a literatura em português sobre essa experiência extraordinária, que comemorando seis décadas de existência, apesar da volumosa literatura presente em outros idiomas, como o inglês, francês ou mesmo espanhol. Com características geográficas parecidas com as da paisagem alagoana, o estado de Kerala tem um território apenas $20 \%$ mais amplo, entretanto uma população dez vezes maior que a de Alagoas, sendo este o quarto estado brasileiro com maior densidade populacional.

A história nos aproxima. Assim como Alagoas, as possessões de Goa, Diu e Damão, no litoral indiano, pertenceram, entre os séculos XV e XIX, ao império português. Existia intercâmbio entre as regiões colonizadas e, nesse período de história comum, enviamos a mandioca, o caju e outras plantas, que por lá se popularizaram. De lá, da Índia, vieram acana-de-açúcar, o coco, a jaca, a fruta-pão, a manga, muitas especiarias, como plantas e condimentos, que, hoje, participam da cozinha e gastronomia nordestina e alagoana. E veio o gado dominante em nossa pecuária, conhecido genericamente como Zebu, mas de nome real Nelore, Guzerá, Gir e outros menos presentes.

Por que temos que olhar para Kerala? Porque, além de uma história com traços comuns, de suas semelhanças com a paisagem de Alagoas, o Estado indiano possui o mais alto IDH entre as 28 unidades que compõem a moderna Índia. Um Índice de Desenvolvimento Humano 0,790 - equivalente ao do Uruguai, mais alto que o de São Paulo ou Santa Catarina. É um valor, portanto, considerado de "alto desenvolvimento" no âmbito internacional e "muito alto" se levarmos em conta a realidade indiana. Esse desenvolvimento social é resultado de algumas variáveis: a elevada expectativa de vida; população mais alfabetizada; menor taxa de mortalidade infantil; e, um dos maiores PIB per capita da Índia. E não só: Kerala, segundo vários organismos internacionais, tem a menor taxa nacional de homicídios, as cidades mais limpas e o maior grau de transparência nas contas públicas.

Como um estado pertencente a um país considerado símbolo da pobreza massiva conseguiu tão bons resultados? A razão é uma só: o estado de Kerala elegeu um governo reformista no final dos anos 1950 e, desde então, em sucessivas eleições e algumas vitórias, foi implantando um modelo de desenvolvimento centrado em investimentos dirigidos à 
erradicação da pobreza, por meio de políticas de saúde e educação públicas, planejamento demográfico e programas sociais produtivos.

O modelo de Kerala está centrado na erradicação da pobreza pela reforma agrária e pelo enfrentamento dos déficits sociais - como o analfabetismo, mortalidade infantil, desemprego, desigualdades de renda etc. - com respostas ambientalmente responsáveis e politicamente participativas. Kerala é, hoje, um centro de visitação de economistas e estudiosos de muitos países que vão à Índia conhecer essa experiência exitosa no sentido do desenvolvimento regional. A Índia possui nove laureados com o prêmio Nobel, alguns deles em Medicina, Física ou Química. O economista premiado Nobel de 1998, Amartya Sen, é um dos divulgadores e entusiastas do modelo de desenvolvimento de Kerala.

Existe na literatura sobre a história recente desse estado indiano um termo que sintetiza as suas múltiplas facetas: o "paradoxo Kerala", cunhado por alguns estudiosos, decorrente do desenvolvimento social antes do crescimento econômico, das mudanças sociais permanentes que foram realizadas em um dos países mais pobres da terra, em plena democracia (a Índia se vangloria de ser chamada "a maior democracia parlamentar do mundo"). E, mais recentemente, esse "paradoxo" está sendo cobrado pelo fato de ser o mais avançado modelo social indiano, mas que não obtém os mesmos desempenhos de outros estados no período recente do "milagre econômico" da Índia.

Região do "paradoxo", Kerala avança muito rapidamente, acumulando uma experiência de seis décadas em políticas de saúde pública, com um sistema universal - a exemplo do SUS que serviu de modelo para outros países e regiões da própria Índia. A medicina moderna (a Índia é um maiores exportadores mundiais de medicamentos) convive, naquele Estado, com as práticas milenares da medicina tradicional ayurveda. Numa sociedade ainda dividida por "castas", em que as mulheres lutam por direitos básicos, Kerala avançou no programa de erradicação total do analfabetismo, com um índice hoje de mais de $90 \%$ de sua população alfabetizada e uma expressiva participação feminina na política e gestão pública.

Tradição e modernidade convivem no universo complexo do "paradoxo Kerala". O primeiro aeroporto mundial totalmente alimentado com energia solar é o da cidade keralesa de Cochim, um antiquíssimo entreposto comercial frequentado pelos portugueses, cidade onde faleceu o navegador Vasco da Gama, em 1524, enterrado que foi na Igreja de São Francisco, o mais antigo templo católico na Índia. A cidade de Calicute, no litoral de Kerala, sedia o programa de popularização da ciência, o KeralaSastraSahithyaParishad (KSSP), muito citado pelos organismos internacionais, com mais de 60 mil participantes, em 2,3 mil clubes espalhados pelas pequenas localidades do interior, que serve de modelo para outros países e regiões. Foi na mesma 
Calicute que, em 1501, o navegador Pedro Álvares Cabral tentou construir uma feitoria portuguesa, contando com a ajuda do nosso bastante conhecido, o escrivão Pêro Vaz de Caminha.

Kerala também é um dos polos indianos de desenvolvimento tecnológico na área de informática. A Índia, sabemos, é uma potência na área da produção de software, considerada "o escritório da economia globalizada" pelo seu domínio na área da tecnologia de informação, um contraponto ao outro vizinho gigante, a China, que seria a "oficina industrial do mundo". É importante dizer que a Índia é também, desde o século passado, uma potência militar e científica. São 28 milhões de estudantes universitários. Desenvolvendo tecnologias próprias em seus institutos de ciências e pesquisas, a Índia testou, em 1974, sua bomba atômica, construiu submarinos nucleares e lançou, este ano, o maior foguete da história espacial, que colocou, simultaneamente, 104 satélites na órbita da Terra, um recorde mundial.

Alguns anos atrás, ouvi o professor Cícero Péricles de Carvalho falar, com entusiasmo, da existência da tese doutoral de Vinicius Lages sobre a experiência de Kerala, orientada pelo professor Ignacy Sachs e apresentada na École des Hautes Études en Sciences Sociales(EHESS), em Paris. É, com alegria que, anos depois, vejo essa pesquisa, realizada em 1998, encabeçando a lista das vinte teses escolhidas pela Fapeal, para ser publicada nas comemorações dos 200 anos de Emancipação de Alagoas.

Com esta edição, podemos finalmente usufruir de um trabalho escrito originalmente em francês, defendido há duas décadas, pelo ex-professor da Ufal, ex-Ministro do Turismo e atual diretor administrativo e financeiro do Sebrae nacional, Vinicius Nobre Lages. Em boa hora, o livro "Kerala" chega para nos mostrar as muitas semelhanças com Alagoas, as possibilidades de aprendizado mútuo entre nós, desde as técnicas agrícolas a tecnologia da informação, desde a biotecnologia a tecnologias sociais, e dizer da importância dessa necessária (re)aproximação histórica, sentimental e cultural entre Alagoas e o estado indiano do Kerala. Boa leitura! 